\begin{abstract}
The 1930s saw a dramatic escalation in the size and scope of the Soviet Union's system of penal labour camps, the Gulag. Through analyses of memoir and other sources, the experiences of the Gulag's prisoners at this time have been the subject of a great deal of scholarly investigation. Yet the guards who watched over these prisoners have received considerably less attention.

Newspapers printed for the VOKhR guards in the mid-1930s offer some information on their readers' every day duties and their status, both inside the Gulag and as citizens of the USSR. Publications taken from one particularly large camp responsible for the construction of the Baikal-Amur railway (BAMlag) depict guards as self-disciplined, industrious soldiers engaged in a war for economic and social development. But the specific dynamics and changing circumstances of the Soviet penal system at this time created an unusual contrast between newspapers printed for the guards and those printed for the prisoners of BAMlag. While the criticism levelled at prisoners by their own newspaper was often mitigated by a rehabilitative discourse, the guards were judged as full members of Soviet society, often harshly. However, the precise implications of this were rendered ambiguous by the indeterminate position of the Gulag itself at this point in Soviet history.
\end{abstract}

Keywords: Guards; Gulag; Soviet Press; Prisoners; VOKhR

\title{
On Guard at BAMlag: Representations of Guards in the 1930s Gulag Press
}

On 1 July 1933, a certain Comrade Gavrilov saw his personal declaration printed on the pages of On Guard at BAM (Na Strazhe Bama), a newspaper printed for security staff at the BAMlag penal labour camp in Soviet Russia's far east. The declaration pledged a portion of the guard's personal income to expedite the work of BAMlag; the construction of the Baikal-Amur railway. Gavrilov offered up 4,500 rubles, or 112.3 percent of his monthly wage, for the good of the camp. His declaration was accompanied with a brief explanation of his decision. Having studied the considerable demands placed on the camp by the second Five-Year Plan, which had been announced earlier that year, he felt moved to give what he could. Proper completion of the new plan was hugely important, he said. He concluded his 
concise intervention by imploring readers to follow his example and make a comparable commitment. ${ }^{1}$

Who was this dutiful and patriotic guard? We may presume something of his background. Gulag guards came primarily from three major groups: the Red Army, the Gulag's prisoner population, and from elsewhere within the NKVD. Had he belonged to the first group, Gavrilov may have been one of those who struggled to readjust to civilian life after leaving the military; demobilized soldiers were more easily encouraged to take a job in the inhospitable places where many camps were established. Alternatively, he would also have lacked employment prospects if he had been a prisoner at BAMlag, and consequently may have chosen to remain in his camp and become a guard, something under-staffed administrators seemed to welcome (or even enforce). ${ }^{2}$ Finally, work in the Gulag was one of the least desirable positions that the NKVD had to offer, so if Gavrilov had come from within that institution he is likely to have suffered the misfortune of demotion. ${ }^{3}$

Less can be surmised about his role after his arrival at BAMlag. With the notable exception of a recently published memoir translated by Deborah Kaple, the vast majority of first-hand accounts of Gulag life have come from prisoners. ${ }^{4}$ Through the study of personal memoir and the analysis of official discourse, the experiences of Gulag prisoners have thus been examined in some detail, but their guards remain relatively obscure figures, occasionally glimpsed from the prisoner's perspective. ${ }^{5}$ During the 1930s, the Gulag

Special thanks are due to Miriam Dobson for her kindness, generosity and support throughout the development of this piece.

1 Na Strazhe Bama, 1 July 1933, in The British Library: The Gulag Press, 1920-1937, Micro Fiche 895, 2.

2 Steven Barnes, Death and Redemption: The Gulag and the Shaping of Soviet Society (Princeton: Princeton University Press, 2011), 48, 51.

${ }^{3}$ Anne Applebaum, Gulag: A History (Penguin: London, 2004), pp. 244-45.

${ }^{4}$ Deborah Kaple, introduction to Fyodor Mochulsky, Gulag Boss: A Soviet Memoir, trans. and ed. Deborah Kaple (Oxford: Oxford University Press, 2011), xxvi.

${ }^{5}$ For further discussion of prisoner memoirs in Soviet history, see: Cynthia Ruder, Making History for Stalin: The Story of the Belomor Canal (Gainesville: University Press of Florida, 1998), 7. J. Arch Getty, The Origins of the Great Purges: The Soviet Communist Party Reconsidered, 1933-1938 (Cambridge: Cambridge University Press, 1985), 4-6. For examples of memoir in use, see: Frierson, Cathy A., and Semyon S. Vilensky. Children of the Gulag (London: Yale University Press, 2010). Nanci Adler, The Gulag Survivor: beyond the Soviet System (London: Transaction Publishers, 2002). Leona Toker, Return from the Archipelago: Narratives of Gulag Survivors (Bloomington: Indiana University Press, 2000). 
steadily increased in size whilst public discussion of it was suppressed, and this put limitations on the literary representations of guards like Comrade Gavrilov. 6 Personnel files in the Central Gulag Archive remain classified, and other archival materials offer little enough information on the numbers of guards working at each camp, and even fewer details on the duties of individual employees. ${ }^{7}$

In this context, the newspaper Na Strazhe Bama represents an isolated window into a life spent guarding one of the Gulag's largest and most significant camps. By 1936, BAMlag held 180,000 inmates, over $20 \%$ of the Gulag's entire prisoner population. ${ }^{8}$ This surely must have necessitated a vast contingent of guards for whom the camp's journalists, the lagkory, wrote. In this piece, issues of $\mathrm{Na}$ Strazhe Bama taken from 1933 to 1936 will be inspected for insights into the role and status of the guards at BAMlag. A smaller but significant number of citations will also come from editions of a second paper, Zorkil Strelok (The Vigilant Rifleman), published for BAMlag's guards in 1935. Observations drawn from these sources are therefore only strictly relevant to the mid-1930s. ${ }^{9}$ The decision to focus on publications from one particular camp at one particular time is intended to keep the material manageable, but some insights into the guards' day-to-day life, their status and the expectations placed upon them by others will apply across the Gulag's huge network of camps.

To be specific, both Zorkil Strelok and Na Strazhe Bama were printed for the Voenizirovannaîa Okhrana (Militarized Guard), often shortened to VOKhR

Nadezhda Joffe vividly depicts the figure of the guard here: Nadezhda Joffe, Back in Time: My Life, My Fate, My Epoch (Michigan: Labor Publications Inc, 1995), 91-97. Aleksandr Solzhenitsyn did write extensively about Gulag guards from a less immediate perspective: Aleksandr Solzhenitsyn, The Gulag Archipelago, 1918-1956: An Experiment in Literary Investigation (London: Harvill Press, 1978),152, 219-227.

${ }^{6}$ Ruder, Making History for Stalin, 144.

${ }^{7}$ Alan Barenberg, 'From Prison Camp to Mining Town: The Gulag and its Legacy in Vorkuta, 1938-1965' (Ph.D. Thesis, University of Chicago, 2007), 63.

8 Oleg V. Khlevniuk, The History of the Gulag: From Collectivisation to the Great Terror (London: Yale University Press, 2004), 108.

9 Whilst this article cites editions of the prisoners' newspaper Stroitel' Bama from the years 1933, 1934 and 1936, the British Library only holds samples of Na Strazhe Bama from 1933 and 1936, and a smaller range of examples from Zorkil Strelok from 1935 alone. Unavoidably, this fact has restricted the scope of the piece. See: The British Library: The Gulag Press, 1920-1937, Mic. F. 895. 
or v/okhrany. ${ }^{10}$ These were the armed contingents of security personnel who patrolled the perimeter of Gulag outposts and escorted prisoners to and from their places of work, ensuring the obedience of inmates and minimising escapes. Consumption of these papers outside the ranks of the VOKhR was strictly prohibited, as repeatedly indicated on the front page of each source. ${ }^{11}$ It is not clear how diligently this rule was obeyed, so we cannot be sure who did read the sources, but we do at least know with real certainty who was supposed to read the sources and therefore who was supposed to be absorbing the messages embedded within.

I will argue that in some respects both Na Strazhe Bama and Zorkil Strelok are conventional publications of their time. Their language contains familiar Soviet tropes and their content is dominated by typical themes and preoccupations. Yet the reflection of Soviet social values in the texts produces a surprising dynamic between guards and their prisoners. A newspaper published for the inmates at the camp, Stroitel' Bama (Builder of BAM), addressed its readers with positive, congratulatory articles celebrating hard work and achievement. In contrast, the guards were treated more critically by their paper, despite their comparably higher status as non-criminals. I attribute this to the legacies of Soviet discourse on correctional punishment, on the one hand, and the ongoing transformation of Soviet society on the other. I also suggest that central administrative organs abdicated discursive influence over the camp's journalists, leaving them over-reliant on established clichés and unwilling to develop a more coherent image of the Gulag guard. I do this first by discussing the source material in more depth, then moving on to review the contents of the guards' papers, both independently and in relation to Stroitel' Bama. The piece ends with a broader analysis of Soviet society in the 1930s in an effort to explain Comrade Gavrilov's position within it.

\section{Analysing Discourse in the Soviet Context}

The generosity of Gavrilov's donation to BAMlag appears diminished by the context in which it was declared, because he was not the only guard to have such a declaration printed in Na Strazhe Bama on 1 July 1933. A number of his colleagues pledged varying amounts of their personal wealth, though their reasons for doing so were expressed in a strikingly uniform way. In a single formulaic sentence of two clauses, every article made reference to

\footnotetext{
10 Na Strazhe Bama, 7 November 1936, 4.

11 The rubric of each paper specifies that editions must not be disseminated beyond the VOKhR. See, for example: Na Strazhe Bama, 10 October 1936, 1. Zorkil Strelok, 17 January 1935, in The British Library: The Gulag Press, 1920-1937, Micro Fiche 895, 1.
} 
the importance of the second Five-Year Plan, which each guard is said to have studied closely. ${ }^{12}$ The homogeneity of the declarations suggests that the camp's contingent of lagkory (a contraction of the Russian for 'camp correspondents') wrote them using a standard format on the guards' behalf, thereby obscuring from the contemporary reader any more personal reason which they could have had for making their donations; they may well have been forced. The high levels of illiteracy amongst labour camp guards might also have compelled the lagkory to offer a helping hand. ${ }^{13}$ Alternatively, the guards may not have been trusted to write something consistent with the newspaper's ideological agenda.

Little is known about the lagkory themselves, whether benevolent ghost writers for illiterate guards or hard-nosed defenders of the state ideology. It is evident from the sources that many of the newspapers' articles, perhaps most of them, were actually written by the guards or at least from their perspective. The same is true of the prisoners' newspaper and its readership, though there is an instructive difference between the two types of publication. When making a written contribution, guards were often referred to as voenkory or 'war correspondents', as if they were writing from the front line, whilst the lagkory submitted their own material and also acted as editors of the guards' pieces. ${ }^{14}$ In contrast, prisoners who wrote for their own paper were ascribed the title lagkory too, suggesting not only that the editing team was made up of prisoners but also that there was little difference between editors and contributors. 15 The distinction between camp and war correspondents in the guards' paper may have been slight, particularly if lagkory were originally guards who had acquired extra responsibilities, but the difference in their titles at least implies some conceptual distinction, with the voenkory in the heat of battle and the lagkory back at base camp. ${ }^{16}$ Ultimately, whether prisoners, guards or employees specially hired for the task, the influence of these editors on the submissions of the readers remains largely incalculable, as does the proportion of any guard's submission which he himself had written. It seems unlikely that ordinary readers would have been granted much freedom to shape their own publication.

12 Na Strazhe Bama, 1 July 1933, 2.

${ }^{13}$ Applebaum, Gulag, p. 245. Fyodor Mochulsky, Gulag Boss: A Soviet Memoir, trans. and ed. Deborah Kaple (Oxford: Oxford University Press, 2011), 38.

${ }^{14}$ Na Strazhe Bama, 20 August 1933, 2. Na Strazhe Bama, 19 September 1936, 4.

${ }^{15}$ Stroitel' Bama, 28 August 1936, in The British Library: The Gulag Press, 1920-1937, Mic. F. 895,1 .

16 We must also consider the possibility that the lagkory working on the guards' papers were actually prisoners, and the same prisoners as those working on Stroitel' Bama. 
Such uncertainty calls into question the value of the source as an authentic representation of the guards' lives. Surrounded as they were by the apparatus of the Soviet penal system, it is probable that the lagkory would have felt pressured to produce articles which were congruent with Soviet ideology, or only accept articles from the voenkory which could be made so, especially since Article 58 had made opposition to the regime illegal in 1926. ${ }^{17}$ By the 1930s, regional publications had learned to mimic the content of central newspapers in order to avoid deviating too far from the party line. ${ }^{18} \mathrm{As}$ a consequence, the newspaper's account of a guard's everyday life is unquestionably incomplete. From 1933, prisoner numbers at BAMlag began to rise rapidly. Many of the new inmates came from areas of the USSR which were in the grip of a serious famine at the time, and arrived malnourished. The camp itself was poorly prepared for this influx and did not have the supplies to feed all of the new arrivals, many of whom starved to death. ${ }^{19}$ No mention of this tragedy can be found in the newspaper, though the effects of the high death rate must have had some kind of prominence in the guards' lives.

The shortcomings of the source material, however, do not render it useless. To suggest that $\mathrm{Na}$ Strazhe Bama was a mouthpiece of a distant political regime, as irrelevant to the everyday lives of BAMlag's security staff as a children's fairytale, is to simplify the relationship between the employees and their media. Scholars have contested the view that the ideological agenda of Soviet propaganda was entirely a product of the Soviet Union's ruling elite. J. Arch Getty, for example, has argued that the Great Purges of the late 1930s could not have been wholly choreographed by central administrative organs. Instead, individuals adopted, altered and reapplied the Communist Party's interpretative framework for a variety of idiosyncratic reasons, contributing to a wave of allegations and arrests. ${ }^{20}$ Jochen Hellbeck deconstructs the binary between people and state slightly differently. In his configuration, Stalinist power not only subjugated the self, but also contributed to its development. Stalinism was both repressive and 'productive'. ${ }^{21}$ In

17 S. Barnes, Death and Redemption, pp. 84-85.

18 Matthew Lenoe, Closer to the Masses: Stalinist Culture, Social Revolution, and Soviet Newspapers (London: Harvard University Press, 2004), 20.

${ }^{19}$ Applebaum, Gulag, 88-89.

20 Getty, The Origins of the Great Purges, 1-6.

21 Jochen Hellbeck, 'Working, Struggling, Becoming: Stalin Era Autobiographical Texts', Russian Review 60 (Jul., 2003): 341. 
adapting the ideology of the Communist Party, whether to promote their own interests or develop their sense of identity, individuals generated a multiplicity of slightly different ideologies. As a result, social and economic policies did not 'uniformly emanate from above...' and do not only reflect the attitudes of the elite. ${ }^{22}$

Reading Na Strazhe Bama and Zorkil Strelok is thus not comparable to reading the transcript of one of Stalin's speeches. Just as regional Gulag administrations took advantage of ambiguities in legislation from Moscow for their own ends, lagkory and voenkory utilised Marxist-Leninist terminology to express something more specific than the national policy of the Communist Party. ${ }^{23}$ What's more, the writers' understanding of this terminology has been affected by the way it was used by those around them. When reading $\mathrm{Na}$ Strazhe Bama, we see a language which has been understood and developed by a host of different individuals, including the guards. When reading about a guard's reaction to the second Five Year Plan, we see more than simply the demands of the regime. We may also determine something of the status and expectations placed on the guards by their social milieu; other guards, camp administrators, prisoners, lagkory and so on. To paraphrase Cynthia Ruder, sources such as Na Strazhe Bama thereby provide us with one of a number of truths. 24

\section{The Guard at BAMlag: Efficient, Productive, Respectable}

A cursory appraisal of $\mathrm{Na}$ Strazhe Bama confirms what might be our instinctive expectations about Gavrilov and his colleagues. First of all, the content of the paper is suffused with militaristic imagery. As well as the more neutral 'guard' (okhrana), readers of the paper were commonly referred to as 'riflemen' (strelki) and 'fighters' (boi $\widehat{T} y$ ). ${ }^{25}$ Martial language was also repeatedly used to describe readers' everyday duties. Guards were encouraged to study 'war theory' (boevaîa teoriia) to aid them in the completion of 'war work' (boevaía rabota). ${ }^{26}$ In particular, the construction

22 Ruder, Making History for Stalin, 5.

23 James R. Harris discusses the limited jurisdiction of Gulag administrators here: James R. Harris, 'The Growth of the Gulag: Forced Labour in the Urals Region, 1929-1931', Russian Review 56 (Apr., 1997): 265-80.

${ }^{24}$ Ruder, Making History for Stalin, 7.

${ }^{25}$ Na Strazhe Bama, 13 January 1936, 1. Na Strazhe Bama, 10 March 1933, 1. Na Strazhe Bama, 10 September 1936, 1.

${ }^{26}$ Na Strazhe Bama, 10 July 1933, 1. 
work of BAMlag was invariably presented as part of a struggle (bor'ba) for the achievement of a particular goal or quota, and the paper presented its readers as soldiers engaged in a war for prosperity. ${ }^{27}$ Given the backgrounds of many guards and the militarised nature of their work, this may come as no surprise. Indeed, in this regard Na Strazhe Bama hardly stands out from the wider Soviet press, which began borrowing heavily from military vocabulary in the 1920s. ${ }^{28}$ Zorkil Strelok exhibits exactly the same tendencies. ${ }^{29}$

As in other Soviet publications, martial language was used in connection with another theme which might naturally appear in labour camp publications: economic development. On 10 July 1933, Na Strazhe Bama carried a frontpage article celebrating the ongoing achievements of the Second Five-Year Plan. Readers were clearly expected to feel directly involved in this progress, as the paper insisted that the 'army' (armiia), meaning the guards, were part of the construction of socialism. ${ }^{30}$ This message was reiterated continually throughout various editions of the paper. In October of the same year, guards were encouraged to engage more fully with topical debates about the advantages of 'socialist competition' (sotsialisticheskoe sorevnovanie). ${ }^{31}$ At a moment of rapid expansion within the Soviet economy and the Gulag, sotsialisticheskoe sorevnovanie was a reference to the various models of industrial production being evaluated at the time. ${ }^{32}$ By asking the guards at BAMlag to consider these different models in some depth, Na Strazhe Bama seems to have been trying to involve them in the USSR's transition from a largely agrarian economy to an industrialised one, and did so metaphorically using military language.

Three years later, guards were still dutifully discussing the USSR's economic transition. One edition of their paper from September 1936 described a meeting of guards from two different brigades. These individuals considered various means of increasing labour productivity, and the names of those guards who had made particularly pertinent contributions to the debate

27 Na Strazhe Bama, 30 September 1936, 2.

${ }^{28}$ Lenoe, Closer to the Masses, 78.

29 Zorkil Strelok, 23 February 1935, 2. Zorkĭ Strelok, 20 July 1935, 1.

30 Na Strazhe Bama, 10 July 1933, 1.

${ }^{31}$ Na Strazhe Bama, 30 October 1933, 1.

32Lewis H. Siegelbaum, 'Production Collectives and Communes and the "Imperatives" of Soviet Industrialization, 1929-1931', Slavic Review 45 (Spring, 1986): 80. 
were listed. ${ }^{33}$ Guards were also asked to evaluate more specific economic initiatives. When economic orders and directives arrived from Soviet administrative organs or the leaders of the camp itself, these were presented by the lagkory in a way which directly implicated their readership. Guards were made to feel that the industrial development of the camp and, by extension, the USSR, was contingent on their efforts. In early 1936 an announcement was published which ordered that every prisoner in each of the Gulag's institutions should increase his or her daily industrial output by one measurement. Articles which accompanied this directive emphasised the role of camp guards in supervising the escalation of productivity. ${ }^{34}$

As guards were conceptualised as warriors engaged in a battle for economic development and, of course, were charged with maintaining discipline at BAM, it is also unsurprising to find that their newspapers expected them to act in a respectable and self-disciplined manner. Again, this is not unlike media printed for other Soviet citizens. ${ }^{35}$ Guards who exhibited exemplary behaviour were often praised for fulfilling a 'leading role' (vedushchaîa rol) which their colleagues could emulate. ${ }^{36}$ Noteworthy or admirable qualities included 'Vigilance, Initiative, Resourcefulness and Determination' (Bditel'nost', Initsiativa, Nakhodchivost' i Reshitel'nost). ${ }^{37}$ Individual guards were often selected for special praise, with their portrait sitting alongside a list of their virtues. On 20 th October 1936 Na Strazhe Bama celebrated the efforts of Comrade Tol'tsev, who had excelled himself during both his working duties and his studies, proved himself a leading propagandist and as an organiser of new productive techniques. ${ }^{38}$

Pieces focusing on a particular guard were very common in 1936 but had the same formulaic quality exhibited by Gavrilov's declaration back in 1933. If Comrade Tol'tSev had read Na Strazhe Bama ten days before his own contributions were recognized, he may not have felt the upsurge in pride

${ }^{33}$ Na Strazhe Bama, 30 September 1936, 2.

${ }^{34}$ Na Strazhe Bama, 31 January 1936, 1-2.

${ }^{35}$ Model citizens were celebrated for a variety of qualities in the civilian press as time went on. See: Vadim Volkov, 'The Concept of Kul'turnost': Notes on the Stalinist Civilizing Process', in Stalinism, New Directions, ed. Sheila Fitzpatrick (London: Routledge, 2000), 21030.

${ }^{36}$ Na Strazhe Bama, 10 July 1933, 1.

37 Zorkĭ Strelok, 20 July 1935, 1.

38 Na Strazhe Bama, 20 October 1936, 2. 
the lagkory had intended, since a Comrade Chichilin's own achievements had been listed on the $10^{\text {th }}$ October 1936 in an unmistakably similar fashion. In fact, one of the few differences between the two articles in question was that Chichilin was also congratulated for coordinating new working methods among the prisoners. ${ }^{39}$

The suggestion that Chichilin or any member of $\mathrm{Na}$ Strazhe Bama's readership were directly involved in the working habits of the prisoners is surprising, since it sits outside the immediate remit of the VOKhR. Chichilin's principle responsibility was camp security. But the source material does occasionally hint at some form of relationship between the guards and their charges.

In October 1936, it was reported that three guards came together to discuss their obligations and review their work. One of the obligations discussed was the 'improvement of the cultural-domestic condition of guards and railway workers [inmates]' (uluchshenie kul'turno-bytovykh uslovii boĭtsov i putearmeitsev). ${ }^{40}$ This same cliché was repeatedly used, though its precise or practical meaning went unexplained. ${ }^{41}$ However, terms such as 'culturaldomestic' had a high degree of flexibility in Soviet discourse. Media under Stalin often directly equated abstract social concepts with menial tasks in everyday life, thereby imbuing mundane activities with a heavy political significance. As Steven Barnes suggests, 'Machines did not just break; industrial accidents were no accident'; these events were often viewed as the product of political or cultural transgression.42 In such an atmosphere, 'cultural-domestic conditions' might have referred to the maintenance of BAMlag's machinery or the cleanliness of its barracks. The three guards may have been discussing these very practical issues, re-conceptualised by the lagkory as the provision of a politically favourable environment. In this instance then, the topic of the guards' conversation does not imply a direct

39 Na Strazhe Bama, 10 October 1936, 2.

40 Na Strazhe Bama, 10 October 1936, 1. The paper consistently refers to prisoners as putearmeitsy, which Thomas Lahusen translates more precisely as Soldier[s] of the Tracks. Thomas Lahusen, How Life Writes the Book: Real Socialism and Socialist Realism in Stalin's Russia (Ithaca: Cornell University Press, 1997), 16. It is noteworthy that forced labourers on the Belomor canal, which will be discussed later, were referred to as kanalarmertsy or, perhaps, Soldier[s] of the Canal. The martial overtones of these phrases clearly connect to the tendency of all three papers towards military metaphors, but for simplicity's sake the word will henceforth be translated as 'inmates'.

${ }^{41}$ Na Strazhe Bama, 19 September 1936, 4.

42 Barnes, Death and Redemption, 54. 
relationship with prisoners, only some awareness of their living and working conditions.

On the other hand, Zorkil Strelok published an article on 23rd February 1935 entitled 'An example for All' (Primer dlia vsekh). In it, riflemen from a particular subdivision are congratulated for their 'cultural-educational work among inmates' (kul'turno-vospitatel'naîa rabota sredi putearmeitsev). Thanks to their efforts, according to the article, a drama group (dramaticheskil kruzhok) had been organised for the prisoners, the effect of which was an improvement of discipline in the camp. ${ }^{43}$ Unlikely as it is that the organisation of dramatic societies was a generalized duty of all members of the VOKhR, the paper brought this activity into focus as an example that its readers should emulate, suggesting that the behaviour and actions of guards could have a direct and positive impact on BAMlag's prisoners.

Similar incidents can be found elsewhere in the source material, and as long as the abstractions and ambiguities of Soviet jargon are negotiated carefully, we begin to move away from more predictable representations of guards and their work. In September 1936, Na Strazhe Bama encouraged its voenkory to write about their everyday lives, including 'educational work amongst inmates' (vospitatel'naîa rabota sredi putearmeǐşykh mass). ${ }^{44}$ On $20^{\text {th }}$ April 1935, Zorkil Strelok described a series of political discussions held between guards and prisoners on matters of discipline and domestic affairs. ${ }^{45}$ Readers were encouraged to imitate these activities, and their association with matters of efficiency and obedience connected them with the overall success of BAM itself.

\section{Redemption and Self-Betterment at BAMlag}

References to educational work are somewhat anomalous alongside the other duties of a guard at BAM. However, they attain greater congruence when read together with contemporaneous issues of Stroitel' Bama (Builder of BAM), a newspaper printed for the prisoners of the camp. Wilson Bell identifies a rehabilitative or redemptive discourse in such newspapers, connecting them with a larger narrative about the transformation of the individual in Soviet society. ${ }^{46}$ Such a process of transformation might be

43 Zorkil Strelok, 23 February 1935, 2.

${ }^{44}$ Na Strazhe Bama, 19 September 1936, 4.

45 Zorkil Strelok, 20 April 1935, 2.

46 Wilson T. Bell, 'One Day in the Life of Educator Khrushchev: Labour and Kul'turnost' in the Gulag Newspapers' Canadian Slavonic Papers 46, no. 3/4 (September-December, 2004). 
concisely encapsulated as perekovka, a word meaning re-forging. In Soviet literature, it came to mean a profound change in which an individual became a better citizen, more beneficial to socialism: the birth of 'The New Soviet Person'. 47 Usually this transformation came after an act of transgression, most often criminality. The improvement may have been tangible, in that a thief may become a labourer, but just as important was a psychological or ideological transformation. ${ }^{48}$ Perhaps the archetypal propaganda piece of the perekovka campaign was the collectively written account of the construction of the Belomor Canal, a major forced-labour project in north-western Russia. ${ }^{49}$ After this collection was published in 1933 discussion of perekovka was steadily erased from public discourse, but the Gulag press continued to refer to a similar conception of rehabilitation beyond this point. 50

Such a revolution of the mind had a civilising effect, referred to by Bell as kul'turnost'. 51 Kul'turnost'became a widely used term in the late Nineteenth Century, relating to preoccupations with hygiene, punctuality and literacy. The Soviets too endorsed these qualities as necessary constituents of the New Soviet Person and the prisoners of BAMlag were not exempt from this imperative. ${ }^{52}$ Their newspaper frequently implored them to consider their personal hygiene, mind their manners, and study closely at classes on literacy, among other things. ${ }^{53}$ One pertinent example comes from an article on female prisoners employed at the camp. The cooking, cleaning and washing that they did was highlighted and celebrated on the front page of Stroitel' Bama, with the expressed intention of creating an atmosphere of respect for these essential members of the camp community. ${ }^{54}$ Prisoners

\footnotetext{
47 David L. Hoffmann, Stalinist Values: The Cultural Norms of Soviet Modernity 1917-1941 (New York: Cornell University Press, 2003), 45.

48 Ruder, Making History for Stalin, 145-47.

49 Belomorsko-Baltĭskĭ kanal imeni Stalina. Istoriīa stroitel'stva 1931 - 1934 gg., eds. Maksim Gor'kiĭ, Leopol'd Averbakh, and Semen Firin (Moscow: Gosudarstvennoe Izdatel'stvo, 1934). Another prominent piece which explored this kind of rehabilitation is Nikolai Pogodin's 1934 play Aristokraty. See: Ruder, Making History for Stalin, 154-164.

50 Miriam Dobson, Khrushchev's Cold Summer: Gulag Returnees, Crime and the Fate of Reform after Stalin (London: Cornell University Press, 2009), 9-10.

${ }^{51}$ Bell, 'One Day in the Life of Educator Khrushchev', 289-292.

52 Hoffmann, Stalinist Values, 45.

${ }^{53}$ Bell, 'One Day in the Life of Educator Khrushchev'.

54 Stroitel' Bama, 28 March 1933, 1.
} 
were therefore not only taught more about the importance of domestic chores, but also to respect women, another part of the Soviet government's ideological agenda. ${ }^{55}$ Society was steadily readopting formerly rejected connections between women and housework, and the paper evidently kept up with these broader fluctuations in attitudes towards gender. ${ }^{56}$

'Shaming rituals', such as lists of poorly performing prisoners or articles criticising the behaviour of alcoholics, were a regular feature in Stroitel' Bama, and also seem to have had a place in the rehabilitative agenda. ${ }^{57}$ These articles were written to highlight areas in a prisoner's life which needed improvement. Their connection to perekovka is reinforced by the manner in which blame is apportioned for problems. Whether directly or indirectly, the lagkory consistently blamed the management staff of BAMlag for issues that arose, whilst being less harsh on their own readership (in this case, the prisoners). For example, when a prisoner Dorashenko was strongly criticised for alcoholism, personal responsibility for his actions was not emphasised. ${ }^{58}$ The stipulation that non-prisoners were at fault often came at the end of an article, as if acting as a consolatory aside for the benefit of the prisoners' feelings. On $7^{\text {th }}$ July 1933, the paper announced the camp's failure to complete its work targets for the previous month. But rather than berating the prisoners for their indolence, this failure was blamed on poorly maintained machinery. The article even made the point that a prisoner may work night and day at a faulty machine and still achieve very little. Again, responsibility for this issue lay with BAMlag's employees, rather than its inmates. ${ }^{59}$

This dynamic of responsibility was also present in articles which praised the work of the prisoners. Prisoners were frequently commended, particularly when they addressed personal inadequacies, something which could easily be interpreted as a stage of perekovka. When two prisoner divisions entered into a voluntary competition with one another to increase their work norms, Stroitel' Bama celebrated their commitment with one caveat. The barracks of one of the divisions was poorly maintained, and this was likely to

55 Hoffmann, Stalinist Values, 23.

56 Wendy Goldman, Women, the State and Revolution; Soviet Family Policy and Social Life, 1917-1936 (Cambridge: Cambridge University Press, 1993), 342-43.

${ }^{57}$ Bell discusses such articles here: Bell, 'One Day in the Life of Educator Khrushchev', 302-307.

58 Stroitel' Bama, 26 February 1934, 1.

59 Stroitel' Bama, 7 July 1934, 1. 
disadvantage the prisoners taking part in the contest. The leadership of the division, who were responsible for such domestic issues, needed to think carefully about how to resolve this situation. 60

The personal responsibility of prisoners was not, of course, forgotten altogether. Mistakes and achievements were still presented as products of an individual's failings or virtues. For persistently refusing to work, prisoners could be listed and criticised without any reference to external circumstances. ${ }^{61}$ This was probably a more accurate representation of reality, since the ameliorative and idealistic principles of perekovka would likely have had a vanishingly small influence over the forbidding realities of Gulag life. 62 Yet perekovka remained a notable feature of the newspaper's agenda, and it was precisely the powerless and wretched position of the prisoners which partly absolved them of responsibility for their environment. The paper could therefore opt to emphasise the prisoners' circumstances when it wished both to draw attention to the prerequisites of perekovka and to avoid suggesting that inmates had wilfully taken a step backwards on their journey towards complete personal transformation. Instead, environmental factors temporarily slowed their 'march' towards redemption. ${ }^{63}$ Re-forging was made to seem inevitable because no prisoner would choose to stop striving for it.

In Stroitel' Bama, then, the personal responsibility of an individual prisoner could be overlooked in favour of environmental factors when the paper wished to employ the language of redemption. However, there were clear lines of accountability when it came to the maintenance of the environmental factors themselves. In the case of the alcoholic prisoner, Dorashenko, the leader of the relevant division was blamed for not compelling him to stop. ${ }^{64}$ Camp staff and authority figures within the prisoners' brigades were all culpable. On close inspection, the content of Na Strazhe Bama and Zorkil Strelok even implies an unlikely role for the VOKhR in the supervision of

60 Stroitel' Bama, 16 March 1934, 1.

61 Stroitel' Bama, 13 March 1934, 2.

62 Galina Ivanova essentially dismisses perekovka as a fiction used solely to promote greater productivity: Galina Mikhailovna Ivanova, Labor Camp Socialism: The Gulag in the Soviet Totalitarian System (London: M.E Sharpe Inc., 1997), 79.

63 In keeping both with the use of military terminology and the sense of perpetual progression, prisoners were often presented as if marching towards one goal or another. For example, note the use of the phrase 'Not one step backwards!' (Ni shagu nazad!) here:

Stroitel' Bama, 7 July 1934, 1.

64 Stroitel' Bama, 26 February 1934, 1. 
perekovka. This might be on a voluntary basis, as in the case of the "culturaleducational' drama group already mentioned, with its additional benefits to camp discipline. But the guards' newspapers charged all their readers with the provision of 'cultural-domestic conditions', and Soviet 'culturedness' (kul'turnost') certainly involved sobriety. ${ }^{65}$ As argued above, 'cultural-domestic conditions' were everyday practical concerns imbued by Soviet terminology with substantial political significance, something which would certainly have implications for a prisoner's behaviour. The 'educational work' discussed in an article from September 1936 can be read in a similar manner. ${ }^{66}$ Education was a core aspect of perekovka, and guards were made to feel responsible for the education of prisoners in some indirect, abstract way as well.

Like the prisoners, guards were also told to pursue their own selfimprovement and cultural refinement. That is, guards were also encouraged to 'work on themselves' (rabotat' nad sobol) by their papers. ${ }^{67}$ One aspect of this regime was physical; guards were pressured to keep fit. A newspaper from March 1933 announced the establishment of project 'Dinamo', an exercise programme all guards were impelled to join. Accordingly, the edition also includes articles expounding the merits of a strong constitution or complaining about the lack of sporting activities at the camp. ${ }^{68}$ As well as general fitness, the paper played a role in recounting the training of guards in specific skills. On 19 September 1936, the paper reported the results of a class held on the proper use of rifles the previous month. Some guards had not exhibited sufficient proficiency or accuracy. However, by the time of the edition's publication this problem had been addressed. 69

The second area of self-improvement, which was far more prominent in the guards' publications, relates to attitudes and opinions. Most obviously, extensive knowledge and proper comprehension of Marxism-Leninism was heavily emphasised. From the sample of newspapers taken, this agenda was first strongly asserted in 1933, when a questionnaire was published on the state ideology. Guards were required to answer questions such as: 'What is class?' and 'What measures are incorporated into the second Five Year Plan

\footnotetext{
${ }^{65}$ Bell, 'One Day in the Life of Educator Khrushchev'.

${ }^{66}$ Na Strazhe Bama, 19 September 1936, 4.

${ }_{67}$ Na Strazhe Bama, 13 January 1936, 2.

68 Na Strazhe Bama, 10 March 1933, 1-2.

69 Na Strazhe Bama, 19 September 1936, 3.
} 
for the eradication of class distinctions?'70 No specific answers are included in the edition, but in general the paper was full of information relating to these questions. Na Strazhe Bama very often published official declarations, speeches by prominent ideologues and quotes from ideological tracts on its pages. ${ }^{71}$ If guards found such articles less than riveting, they could presumably also get their answers from the political classes which their paper repeatedly ordered them to attend. ${ }^{72}$ Non-attendees were occasionally named and shamed. ${ }^{73}$ The camp journalists left no doubt that learning Soviet ideology was a matter of personal betterment. By late 1936, lagkory regularly honoured a particular guard with a portrait and brief list of qualities which made him exemplary. A good grasp of Marxism-Leninism appears to have been essential. ${ }^{74}$

The pursuit of kultur'nost' is also present in both papers. In May 1935 Zorkil Strelok complained that the guards of a particular brigade were not holding enough political classes, but remarked that at least in Garrison 30 musical instruments are being played. ${ }^{75}$ In the interests of creating a more civilised contingent of guards at BAMlag, $\mathrm{Na}$ Strazhe Bama denounced card games, drunkenness and unsanitary conditions, equating them all with 'unculturedeness' (nekul'turnost). ${ }^{76}$ Often, related issues are referred to as the 'little things' (melochi) which guards are assumed to have forgotten. In November 1933 a Comrade Gavrilov (potentially the same Gavrilov who had committed some of his personal income to the camp four months earlier) is criticised for forgetting about melochi, including keeping bed linen clean, boiling water, and the 'struggle with lice' (bor'ba s klopamy). ${ }^{77}$

Guards were expected both to transform themselves and, ideally, to enable the transformation of their prisoners. However, there was a

70 Na Strazhe Bama, 20 September 1933, 2.

71 This edition is a particularly good example of this tendency: Na Strazhe Bama, 31 January 1936.

72 Solzhenitsyn describes these classes as a means of alienating the guards from the prisoners: Solzhenitsyn, The Gulag Archipelago, 220.

${ }^{73}$ Na Strazhe Bama, 19 September 1936, 3.

${ }^{74}$ Na Strazhe Bama, 10 October 1936, 2. Na Strazhe Bama, 20 October 1936, 2.

75 Zorkil Strelok, 13 May 1935, 1.

${ }^{76}$ Na Strazhe Bama, 30 September 1936, 3.

77 Na Strazhe Bama, 20 November 1933, 1. 
fundamental difference between the transformative process of the prisoners and that of the guards. According to the doctrine of perekovka, the status of a prisoner involved in the process of self-improvement is set into an upward trajectory. Their lowly rank gives them something from which to emerge, meaning that self-improvement in the prisoners' newspaper fits snugly into the Soviet discourse of redemption. Guards, in contrast, were state employees. They may have been poorly educated, located at the bottom of the NKVD's hierarchy and were often ex-prisoners, but the very fact that some had been liberated from the Gulag itself surely meant that any act of rehabilitation had already been completed. If someone has nothing to atone for, it is difficult to present his or her act of self-improvement as essentially redemptive. Selfbetterment was not necessarily the same as redemption or rehabilitation. Prisoners were being rehabilitated at BAMlag, but their guards were undertaking a distinctly different journey.

Articles on self-improvement in Na Strazhe Bama and Zorkil Strelok therefore appear to have been informed by different, more relevant elements of Soviet discourse. Though they were not necessarily conceptualised as criminals or deviants, all Soviet citizens in the early 1930s were expected to undergo a change of some kind. For guards, as with other non-criminals, less emphasis was placed on the attainment of a new, higher social position. Rather, their transformation was written into a more extensive narrative about the creation of a new socialist society free from selfishness and egotism. This phenomenon was defined very broadly. ${ }^{78}$ The mere act of work itself, taking place in the Soviet environment, was felt to have a transformative quality. ${ }^{79}$ More specifically, education and ritual were used in the army and industrial workforce to teach people the history of their various collectives and foster a sense of solidarity and interconnectedness. ${ }^{80}$ Instead of rejoining the collective, it might be said that non-prisoners (guards) were part of the transformation of the collective itself.

Though subtle, these important differences manifested themselves in newspaper print. When guards did read about moments of redemption amongst their colleagues, they were of a less fundamental nature. When Comrade Gavrilov was pilloried for uncivilised behaviour, he was given the

\footnotetext{
${ }^{78}$ For discussion of various forms of social transformation within Soviet society, see: Volkov, 'The Concept of Kul'turnost', 217-28. Jochen Hellbeck, 'Fashioning the Stalinist Soul: The Diary of Stepan Pudlubnyi, 1931-1939', in Stalinism, New Directions, ed. Sheila Fitzpatrick (London: Routledge, 2000), 77-116.

79 Sheila Fitzpatrick, Everyday Stalinism (Oxford: Oxford University Press, 1999), 75.

80 Hoffmann, Stalinist Values, 47-52.
} 
opportunity to publish a written response in the same edition of the paper. Unlike a celebratory article written by the prisoner Nadia Kondratenko in Stroitel' Bama, which contrasted her happy future beyond the Gulag to her transgressive behaviour prior to arrest, Gavrilov's sober and business-like entry contained a list of remedial measures he had taken and the improvements they yielded. Gavrilov had not undergone a radical transformation; he had merely developed. ${ }^{81}$

As a consequence, the prisoners' newspaper connected certain topics and events with a redemptive discourse, whilst the guards' newspapers made no such association. In 1934, the writers of Stroitel' Bama described education as the means by which prisoners could join the ranks of the newly transformed. ${ }^{82}$ Not long afterwards, Na Strazhe Bama presented education as an opportunity for the guards to learn more about themselves, about their personal strengths and weaknesses, in preparation for the party purge (the chistka, which will be returned to shortly). ${ }^{83}$ Thus, education amongst the guards had a closely connected but still different purpose.

Similarly, an edition of Na Strazhe Bama from autumn 1936 contained an article about a group of fifty-six guards who travelled from BAMlag to a nearby collective farm. The guards worked hard to help gather in the farm's harvest, and returned to the camp feeling morally satisfied that they had helped fellow Soviets. They relished the act of physical labour in the same way that re-forged prisoners were expected to do. Yet the writer of the article made no reference to a moral transformation amongst these guards, as might be expected in Stroitel' Bama.84 Though the story may have been included as an example of virtuous behaviour, readers were not encouraged to see selfimprovement as a product of the act. The guards demonstrated a concern for the collective at the farm; they did not acquire it.

The present source material therefore evidences a major difference between the status of guards and prisoners at BAMlag, relating to identity and redemption in Soviet discourse. However, it also contains signs of the unexpected consequences of this very difference. One of the effects of perekovka for the prisoners was the diminishment of personal responsibility. The mistakes and failures of BAMlag's inmates were often blamed on

\footnotetext{
81 Na Strazhe Bama, 20 November 1933, 1.

82 Stroitel' Bama, 9 January 1934, 1.

${ }^{83}$ Na Strazhe Bama, 10 March 1933, 1.

${ }^{84}$ Na Strazhe Bama, 26 September 1936, 2.
} 
environmental or administrative factors beyond the prisoners' control. The guards of BAMlag, bearing a different and more static identity, had no such excuse. The socialist or collectivist impulse, as demonstrated by the guards at the farm, already existed within them. In no need of re-forging, guards were therefore assumed capable of supervising themselves, and were more often held personally accountable for their own mistakes. This is best exemplified in $\mathrm{Na}$ Strazhe Bama by the irregular inclusion of a series of articles entitled 'Is it True?' (Verno Li?), which presented lists of moderate mistakes committed by guards. Such articles included conciliatory, positive remarks less frequently than their counterparts in Stroitel' Bama. Further, only the guard who committed the mistake was held directly responsible in most cases. ${ }^{85}$

The personal responsibility of BAMlag guards was also underlined in articles which described isolated incidents. In January 1936, a group of camp employees was overheard claiming that their working duties left them no time for political study. Those same employees may have read their remarks reported in Na Strazhe Bama later that month, in an unsympathetic article thick with sarcasm. The writer argued in this piece that no such excuse was valid. These idlers only had themselves to blame for missing classes. ${ }^{86}$ Guilty guards could be accused of losing something positive about themselves, such as when Comrade Aksenov drank himself into unconsciousness on a train and was said to have lost his 'class vigilance' (klassovaîa bditel'nost). ${ }^{87}$ Guards who were criticised for a particular failing in this manner, and who subsequently pledged to change their ways, were not forgotten about. Their papers updated readers on the behaviour of their colleagues, and if insufficient progress had been made, they were again held to account. 88

Very often accusations passed between guards from one edition to the next. A particular contributor may have defended his innocence by implicating one of his colleagues. By contesting only which guard was to blame, they reinforced the view that guards generally were responsible for their own actions. A certain Comrade Kononov even criticised the behaviour of his colleagues in order to emphasise his own achievements in improving conditions within his brigade. ${ }^{89}$ Such allegations rarely passed from prisoner to prisoner on the pages of Stroitel' Bama.

${ }^{85}$ Na Strazhe Bama, 20 November 1933, 2.

${ }^{86}$ Na Strazhe Bama, 31 January 1936, 2.

87 Zorkil Strelok, 20 April 1935, 2.

${ }^{88}$ Na Strazhe Bama, 10 October 1936, 1.

89 Na Strazhe Bama, 4 October 1936, 3. 
Whilst holding their readers responsible for their own self-development, the guards' newspapers also reminded them of the consequences of failure. A culpable individual could be punished. A particularly clear example of this is the repeated references to the party purges. From 1929-1931, membership of the Communist Party more than doubled, leading to fears about an everexpanding political bureaucracy populated by opportunists without the required understanding of Bolshevik ideology. Two solutions to these concerns were implemented. The first was a mass-education campaign. The second was a 'traditional party purge', involving investigations into the background and political views of thousands of individual citizens. ${ }^{90}$ Those who failed to meet the standards of the Soviet investigators in the mid-1930s may have been publicly denounced, demoted or even imprisoned. 91

The guards of BAMlag were subjected to both these policies. It has already been asserted that guards were pressured by their paper to attend classes and complete questionnaires. This encouragement was usually accompanied by an explicit warning; studying was the only way to survive the purges. As the frenzy of the purges approached its peak in 1937 and 1938, people were more frequently incarcerated after investigation. As it was a guard's job to supervise such people, the threat of the purge would have become ever more prominent in any guard's mind as the decade went on. This concern was probably intensified by the fact that many of these purge victims were former colleagues; it was very common for Gulag guards to become prisoners at their camp for illegal behaviour. ${ }^{92}$ On 13 May 1933, Na Strazhe Bama's front-page article underlined how soon the next purge would be enacted, and explained that 'self-criticism' (samokritika) and a strong theoretical understanding of Marxism was an essential part of preparing for it. ${ }^{93}$ Later that year, guards were again told that little time remained before the next purge. ${ }^{94}$ Clearly, guards were made to feel that the purge was an everimminent threat.

The reference to 'self-criticism', and the menacing discussion of the purges more generally, allude to what Igal Halfin describes as the communist

90 Getty, The Origins of the Great Purges, 21-22.

91 Ibid., 38-44.

92 Applebaum, Gulag, 242-43.

${ }_{93}$ Na Strazhe Bama, 13 May 1933, 1.

94 Na Strazhe Bama, 20 June 1933, 1. 
'hermeneutics of the soul'. ${ }^{95}$ According to Halfin, early Soviet morality was informed by the communist view that the actions of individuals had no influence on the progress of history, which instead was driven by major economic forces. The logical extension of this was that individuals could not be held wholly accountable for their actions. Instead, they were victims of economic circumstance. The 1930s witnessed a backlash against this attitude. In a similar fashion to Judeo-Christian morality, Soviet society began emphasising a criminal's personal intentions prior to their act of transgression. It was believed that a person who knew and understood how to lead a good life (by Soviet standards), and failed to do so, could be righteously condemned. 96 Halfin's use of the word 'hermeneutics' refers to the complex process of establishing intention, which was closely related to ideological conviction. 'Self-criticism', which Gulag guards were expected to employ, was one method of ascertaining the intentions behind a transgressive act. It often involved a concise autobiography, written by the perpetrator, which sought to explain the act of criminality in terms of their fluctuating commitment to Bolshevik ideology and their personal circumstances. ${ }^{97}$

The contents of the present source material confirm Halfin's argument. As non-criminal Soviet citizens, the guards at BAMlag were obligated to pursue self-betterment as part of the creation of a new socialist society. By 1933, responsibility for this and the proper fulfilment of other duties was accredited primarily to the guard(s) in question. Subsequently, BAMlag's $V O K h R$ were warned of the consequences of failure and told to prepare for inspection, in the form of the chistka. Any mistakes that were made could be treated as an act of political defiance for which a guard could be denounced, so a confident understanding of Marxism-Leninism was presented as a way of avoiding political transgression. ${ }^{98}$ This is in contrast to the prisoners of the camp. In a sense, prisoners had already been purged (even if they had not suffered a chistka), and now their paper suggested that, through work, they could return to Soviet society. The revival of personal responsibility taking place in that society appears to have had fewer implications for them. As a result, their newspaper contained fewer implicit threats about demotion or further punishment.

95 Igal Halfin, 'Looking into the Oppositionists' Souls: Inquisition Communist Style', Russian Review 60 (July, 2001): 317.

96 Ibid., 317-324.

${ }_{97}$ Fitzpatrick, Everyday Stalinism, 135.

${ }_{98}$ Barnes, Death and Redemption, 47. 
As newspapers from BAMlag confirm Halfin's argument, so too does Halfin's argument explain some of the unexpected aspects of the newspapers' content. The stern, critical tone of the guards' newspapers, in contrast with the relentlessly (even exhaustingly) positive, more celebratory spirit of Stroitel' Bama, may seem counterintuitive. One might expect that prisoners in a penal labour camp would be provided with sobering propaganda which reminded them of their lowly status as lawbreakers, whilst the guards would receive more encouraging publications. But these newspapers reflected the dynamics of Soviet ideology which influenced discourse in the mid-1930s. The status of a prisoner was always climbing upwards, whilst the status of a guard was always striving not to fall. The lagkory treated them as such.

\section{Isolation and Ambiguity at BAMlag}

Reading guards' and prisoners' newspapers side by side may reveal something of the relative status of the guards, both in the camp and in Soviet society more generally. The imperative of self-betterment was understood as the responsibility of each individual guard, but it was an imperative he or she shared with any other ordinary member of Soviet society, and the particular duties specific to being a guard at BAM remain relatively obscure. The main task of the VOKhR was the maintenance of security. Exactly how a group of generally illiterate, under-resourced and over-worked security staff might be able to teach a diverse cohort of prisoners the refinements of modern Soviet life is seldom explained. ${ }^{99}$ Yet their papers persistently encouraged guards to take care of the prisoners' 'cultural-domestic conditions' and to set a good example. Why ascribe them duties they were barely able to fulfil, and then offer such little instruction?

The lagkory were not only reticent on the question of a guard's part in the rehabilitation of prisoners. The articles they edited avoided precise or detailed commentary on any aspect of a guard's role. Some of the most striking equivocation relates to discipline. Discipline is closely connected to economic activity in the paper. To consolidate the successes of the Second Five-Year plan in July 1933, for example, guards were asked to maintain and improve discipline as well as to improve the speed and quality of their own work. 100 Such requests appeared in various articles up to 1936, when the paper suggested that a lack of discipline was to blame for the inadequate

\footnotetext{
99 Barenberg describes Gulag camps as having a 'diverse multinational population'. Barenberg, 'From Prison Camp to Mining Town', 61. On shortages and related problems, see: Applebaum, Gulag, 187-193.
}

100 Na Strazhe Bama, 10 July 1933, 1. 
work produced by a number of the guards' brigades. ${ }^{101}$ However, it is not clear from these examples whether the lagkory had in mind discipline amongst prisoners or guards. Discipline was only discussed in highly abstract terms. The means of achieving it - the threatening gestures of a rifle butt described by Lev Razgon in his prisoner's memoir, for example - were never mentioned. 102 Nor were any of the punishments outlined by Aleksandr Solzhenitsyn in his famous portraits of Gulag life. ${ }^{103}$ We might not expect the paper to contain the same vivid depiction of authority found in Razgon and Solzhenitsyn's accounts, but discipline was never even defined explicitly. Why not offer a fuller explanation of the guards' more important duties?

One potential explanation for these questions connects to the ambivalence with which the Soviet political elite related to the Gulag and its personnel. This created an uncertainty which characterised the discourse surrounding the identity and role of the Gulag's security staff, as exemplified in Na Strazhe Bama. It is an ambivalence which seems to have again been informed by the idiosyncrasies of Soviet ideology, and can best be understood through a comparison between the guards' newspapers and publications meant for consumption outside the Gulag. In brief: as perekovka disappeared from public discourse (although not from in-camp literature meant for the prisoners), so too did a key justification for the use of forced labour, and no alternative was forthcoming from the centre. The purpose of the camps thus went unexplained, and the journalists of BAMlag lost a clear sense of the guards' raison d'etre.

In the early 1930s, when the concept of perekovka was at its most prominent, some Soviet propaganda made the claim that guards were not needed to supervise the forced labourers constructing the Belomor Canal. Convicts, apparently content in the knowledge that their physical exertion would cleanse them of their criminal urges, were described happily going about their work without coercion. 104 This image reveals the significance of the Soviets' redemptive discourse in the justification of penal labour; the

101 Na Strazhe Bama, 13 January 1936, 1.

102 Lev Razgon, 'Jailers', in Gulag Voices, An Anthology, ed. Anne Applebaum (London: Yale University Press, 2011), 146.

${ }^{103}$ As well as violence, intimidation and solitary confinement, these include being made to sit in the snow or enduring deliberately drawn out administrative procedures. Aleksandr Solzhenitsyn, One Day in the Life of Ivan Denisovich (London: Bodley Head, 1971). Solzhenitsyn, The Gulag Archipelago, 59.

${ }^{104}$ Ruder, Making History for Stalin, 132. 
promise of perekovka was so strong, it negated the 'forced' aspect of forced labour. The most famous piece of literature regarding Belomor, the completion of which was a huge propaganda coup for Stalin at the time, was an account of the canal's construction collectively written by a host of Soviet writers. ${ }^{105} \mathrm{It}$ was briefly promoted as a new model of Soviet literature, yet it was also the last substantive piece of public propaganda to promote perekovka.106 Although the book did not deny the presence of guards at Belomor's construction site, it described countless incidents of rehabilitation amongst the convicts as justification for their incarceration. Even the newly redeemed criminals themselves were said to immediately understand the rationale for their imprisonment once their own rehabilitation was completed. ${ }^{107}$

Chapter Five of the book was entitled 'The Chekists'. These were members of the Soviet secret police force, which had been called the Cheka until 1922. Though the name of the organisation changed several times, use of the word Chekist to describe a government agent remained in the Soviet lexicon. The subjects described in Chapter Five were state employees charged with keeping order amongst the labourers at Belomor, the same task later entrusted to the guards of BAMlag. In fact, as the Cheka became the NKVD, the Chekists of Belomor might be described as precursors to the Gulag's security staff. Ruder has surveyed representations of the Chekist in the book on Belomor and other literature from the period. Despite a certain thematic incoherence, which she attributes to the practice of collective authorship, Ruder notes some clear consistencies within the book and across different literary works. She describes the archetypal Chekist as 'intelligent, self-assured, and iron-willed' and 'one whom others can try to emulate'. ${ }^{108}$ Closely involved in the process of perekovka, particularly with regard to encouraging self-criticism and educating prisoners, the Chekist assumed the role of a stern but loving parent: paternalistic, forgiving, instructive. 109

The volume on Belmor was a kind of swan song for the perekovka movement. Though it and other pieces considered by Ruder were published in 1934, by which time Na Strazhe Bama had produced numerous issues, the

105 The Joseph Stalin White-Sea Baltic Canal, eds. Gorky, Averbakh and Firin.

106 Greg Carleton, 'Genre in Socialist Realism', Slavic Review53, no. 4 (Winter, 1994): 994. Ruder, Making History for Stalin, 10.

107 Ruder, Making History for Stalin, 118-125.

108 Ibid., 115, 116.

109 Ibid., 162. 
Belomor Canal had already been open a year. The writers who reported on its construction could treat it as history, with the luxury of hindsight, and their collaborated efforts were tightly choreographed by state administrators. Contrast this with the lagkory of BAMlag, who wrote and edited an ongoing commentary for an expanding camp just as the Gulag became a closely guarded secret. ${ }^{110} \mathrm{It}$ would be difficult to prove that Soviet officials lost interest in the rehabilitation of criminals at this time because state secrets like the Gulag require no public justification. Other cultural and political issues were likely to have had an impact. Support for the correctional punishment of counterrevolutionary criminals had already begun to recede in the mid-1920s. As time went on, the broadening definition of counterrevolutionary crime would therefore have narrowed the scope of rehabilitative activities to fewer and fewer prisoners. ${ }^{111}$

Whatever prompted perekovka's withdrawal from Soviet mass media, the effect of this silence on Na Strazhe Bama and Zorkil Strelok would have been the same. Matthew Lenoe indicates that small-scale localised newspapers had already learned to 'cleave tightly to the central press's line' by the early 1920s. ${ }^{112} \mathrm{~A}$ decade later, this central press was providing BAMlag's lagkory with little material to draw from when describing the role of a guard. Perekovka had become outmoded, rendering the didactic role of a Chekist at Belomor inapplicable. True, the redemptive qualities of the Gulag were still discussed on the pages of the prisoners' newspaper, but the guards' papers were addressing state employees who would have had greater awareness of the fluctuations of Soviet morality outside the Gulag, where redemption was losing its prominent position. However, because discussion of the Gulag in the central press was forbidden, no alternative to perekovka was available. The mainstream newspapers were unable to form a new, officially sanctioned narrative around forced labour in the USSR, leaving camp newspapers bereft. Soviet individuals were able to adopt and adapt the language of the regime (as already argued), but the journalists lacked a prototype image of a contemporary guard to work with. Given the tense political atmosphere of the time, it is likely that the lagkory feared the consequences of creating their own unique vision of a guard.

\footnotetext{
110 David J. Dallin and Boris I. Nicolaevsky, Forced Labour in Soviet Russia (New York: Octagon Books, 1974), xii.

111 Barnes, Death and Redemption, 84-85.

112 Lenoe, Closer to the Masses, 20.
} 
The journalists of BAMlag responded to these circumstances by opting for an incoherent muddle of roles and obligations, using various themes such as efficiency, discipline and education without ever relating them to the practical, everyday work of a guard. Some of these themes seem to be inspired by perekovka, with the hazy references to education and role models as the legacy of this dated idea. The Belomor volume offered readers favourable personal characteristics and described the guards' duties in a descriptive, literary language. Na Strazhe Bama and Zorkil Strelok occasionally encouraged their readers to improve BAMlag's 'cultural-domestic conditions', and struggled to place these demands within the day-by-day duties of the VOKhR. Most indicatively, newspaper writers only rarely mentioned the prisoners, despite their central place in the camp's activities. To discuss the prisoners would have been to discuss the guards' attitudes and behaviour toward them, and this was a step requiring more creativity than a camp journalist would allow him or herself. Reliance on military tropes was a comparably safe choice, given the widespread reappearance of these civil war clichés in non-Gulag publications. ${ }^{113}$ As a result, the characteristics of discipline, enthusiasm, of leading by example, were ascribed to the guards but could really have been applied to any Soviet citizen. They were not particularly specific to the guards' job.

The reticence of the central press was mirrored by an administrative ambivalence which gave guards remarkable scope to define their own role. Various prisoner memoirs describe this element of personal discretion. ${ }^{114}$ Nadezhda Joffe, for example, was imprisoned in a Gulag camp in early 1936. Her memoir consistently refers to the temperament of a guard as the deciding factor in how he treated prisoners, noting the variety of ways in which each man interpreted his duties. ${ }^{115}$ The situation does not appear to have changed a great deal as time went on. Fyodor Mochulsky claims to have had a staggering degree of freedom when working as a camp manager in the early 1940s in Pechorlag. ${ }^{116}$ Freedom and personal discretion among the managers surely trickled down into the guards' jurisdiction too. It is

113 Ibid., 11-13.

114 Applebaum, Gulag, 252-253.

115 Joffe, Back in Time, 91-97.

116 Mochulsky, Gulag Boss, 31-38. 
characteristic of a chaotic penal system in which many employees, including guards, exercised unlimited power over prisoners and other staff. ${ }^{117}$

It seems likely that this situation would have both contributed to and resulted from the ambiguities of Na Strazhe Bama and Zorkil Strelok. With such a wide variety of individuals all keeping order in BAMlag as they saw fit, it is little wonder that the camp's journalists struggled to construct a unifying narrative. Equally, lack of instruction from the media would have intensified the feeling amongst guards that they could choose how to behave, though this would have been tempered by the newspaper's stern criticism of those who broke certain behavioural norms. Nevertheless, by leaving camp newspapers struggling to codify a guard's role, the central press compromised its ability to influence low-level Gulag employees.

\section{Guarding the Gulag in the New Soviet Union}

Starting with a simple dichotomy between Gulag prisoners and free Soviet citizens, guards were treated more like the latter. The critical, condemnatory tone of Na Strazhe Bama and Zorkil Strelok belied the social status of their readership. Guards were held personally responsible for their actions and had to pursue the goal of self-development or risk denunciation, but in fact these were some of the dubious honours awarded to non-criminals in the Soviet Union. It was exactly these qualities which defined them as ordinary citizens. The prisoners of BAMlag, in contrast, were still classified as Soviet citizens in the making. Amid the harsh realities of their daily existence, they were encouraged and praised for having this transitional identity, though it nevertheless cost them their freedom.

What we see from the selected source material is a collection of individuals whose complex and imprecise identity is a reflection of the state they worked for. Lacking an officially sanctioned archetype, the writers of $\mathrm{Na}$ Strazhe Bama opted to place heavy emphasis on the guards' place within a changing society. Though granted a stable identity comparable to that of an ordinary citizen, guards were part of a relatively new country striving to establish itself, and could not afford to sit motionless. The USSR was transforming into a modern, industrial nation, and the guards were asked to engage mentally and physically with its construction, internalising the change as soldiers engaged in a war for industrial development. Whether he wrote his article or not, Comrade Gavrilov exemplified this earnest desire for expansion

117 L. I. Borodkin, 'Trud v Gulage: Mezhdu prinuzhdeniem i stimulirovaniem', in GULAG: Ékonomika prinuditel'nogo trud, eds. L. I. Borodkin, P. Gregory, O. V. Khlevniük. (Moscow: ROSSPĖN, 2005), 129. 
and prosperity, the sense of an individual contributing somehow to historical progress on the pages of his newspaper.

\section{Bibliography}

\section{Primary Sources}

Na Strazhe Bama, in The British Library: The Gulag Press, 1920-1937, Micro Fiche 895.

Stroitel' Bama, in The British Library: The Gulag Press, 1920-1937, Micro Fiche 895.

Zorkil Strelok, in The British Library: The Gulag Press, 1920-1937, Micro Fiche 895.

\section{Secondary Sources: Books}

Adler, Nanci. The Gulag Survivor: beyond the Soviet System. London: Transaction Publishers, 2002.

Applebaum, Anne. Gulag: A History. London: Penguin, 2004.

Barnes, Steven. Death and Redemption: The Gulag and the Shaping of Soviet Society. Oxford: Princeton University Press, 2011.

Borodkin, L. I., P. Gregory, O. V. Khlevniük. GULAG: Ékonomika prinuditel'nogo truda. Moscow: ROSSPĖN, 2005.

Brooks, Jeffrey. Thank You, Comrade Stalin! Soviet Public Culture from Revolution to Cold War. Princeton: Princeton University Press, 2000.

Conquest, Robert. The Great Terror: A Reassessment. London: Hutchinson, 1990.

Dallin, David J., and Boris I. Nicolaevsky. Forced Labour in Soviet Russia. New York: Octagon Books, 1974.

Dobson, Miriam. Khrushchev's Cold Summer: Gulag Returnees, Crime, and the Fate of Reform after Stalin. London: Cornell University Press, 2009. 
Dugin, A. N.. Neizvestny̆ GULAG: Dokumenty i fakty. Moscow: Nauka, 1999.

Fitzpatrick, Sheila. Everyday Stalinism, Ordinary Life in Extraordinary Times: Soviet Russia in the 1930s. Oxford: Oxford University Press, 1999.

Frierson, Cathy A., and Semyon S. Vilensky. Children of the Gulag. London: Yale University Press, 2010.

Getty, J. Arch. The Origins of the Great Purges: The Soviet Communist Party Reconsidered, 1933-1938. Cambridge: Cambrige University Press,1985.

Getty, J. Arch, and O'leg V. Naumov. Yezhov: The Rise of Stalin's "Iron Fist". New Haven: Yale University Press, 2008.

Goldman, Wendy. Women, the State and Revolution; Soviet Family Policy and Social Life, 1917-1936. Cambridge: Cambridge University Press, 1993.

Gor'kiĭ, Maksim, Leopol'd Averbakh, and Semen Firin, eds.. BelomorskoBaltiıskil kanal imeni Stalina. Istoriiâ stroitel'stva 1931 - 1934 gg. . Moscow, Gosudarstvennoe Izdatel'stvo, 1934.

Halfin, Igal. Terror in my Soul: Communist Autobiographies on Trial. London: Harvard University Press, 2003.

Hoffmann, David L. Stalinist Values: The Cultural Norms of Soviet Modernity 1917-1941. New York: Cornell University Press, 2003.

Ivanova, Galina Mikhailovna. Labor Camp Socialism: The Gulag in the Soviet Totalitarian System. London: M. E Sharpe, 1997.

Joffe, Nadezhda. Back in Time: My Life, My Fate, My Epoch. Michigan: Labor Publications Inc, 1995.

Kharkhordin, Oleg. The Collective and the Individual in Russia: A Study of Practices. Berkeley: University of California Press, 1999.

Khlevniuk, Oleg V. The History of the Gulag: From Collectivisation to the Great Terror. London: Yale University Press, 2004.

Kokurin, A. I., N. V. Petrov, and V. N. Shostakovskiĭ, eds. GULAG $1918-$ 1960: Dokumenty. Moscow: Mezhdunarodnyĭ Fond "Demokratiia", 2000. 
Kotkin, Stephen. Magnetic Mountain: Stalinism as a Civilization. Berkeley: University of California Press, 1995.

Lahusen, Thomas. How Life Writes the Book: Real Socialism and Socialist Realism in Stalin's Russia. Ithaca: Cornell University Press, 1997.

Lenoe, Matthew. Closer to the Masses: Stalinist Culture, Social Revolution, and Soviet Newspapers. London: Harvard University Press, 2004.

Mochulsky, Fyodor. Gulag Boss: A Soviet Memoir. Translated by Deborah Kaple. Oxford: Oxford University Press, 2011.

Ruder, Cynthia. Making History for Stalin: The Story of the Belomor Canal. Gainesville: University Press of Florida, 1998.

Solzhenitsyn, Aleksandr. One Day in the Life of Ivan Denisovich. London: Bodley Head, 1971.

Solzhenitsyn, Aleksandr. The Gulag Archipelago, 1918-1956: An Experiment in Literary Investigation. London: Harvill Press, 1978.

Suny, Ronald Grigor. The Soviet Experiment: Russia, the USSR and the Successor States. Oxford: Oxford University Press, 1998.

Toker, Leona. Return from the Archipelago: Narratives of Gulag Survivors. Bloomington: Indiana University Press, 2000.

Vilensky, Simon. Till My Tale is Told: Women's Memoirs of the Gulag. London: Virago, 1999.

Viola, Lynne. The Unknown Gulag: The Lost World of Stalin's Special Settlements. Oxford: Oxford University Press, 2007.

Werth, Nicolas. Cannibal Island: Death in a Siberian Gulag. Woodstock: Princeton University Press, 2007.

\section{Secondary Sources: Articles}

Barnes, Steven. 'In a Manner Befitting Soviet Citizens": An Uprising in the Post-Stalin Gulag'. Slavic Review 64 (Winter, 2005): 823-50. 
Bell, Wilson T.. 'One Day in the Life of Educator Khrushchev: Labour and Kul'turnost' in the Gulag Newspapers'. Canadian Slavonic Papers 46, no. 3/4 (September-December, 2004): 289-313.

Borodkin, L. I.. 'Trud v GULAGE: Mezhdu prinuzhdeniem i stimulirovaniem'. In GULAG: Ékonomika prinuditel'nogo truda, edited by L. I. Borodkin, P. Gregory and O. V. Khlevniuk, 129-156. Moscow: ROSSPĖN, 2005.

Carleton, Greg. 'Genre in Socialist Realism'. Slavic Review53, no. 4 (Winter, 1994): 992-1009.

Clark, Katerina. 'The Cult of Literature and Nikolai Ostrovskii's "How the Steel Was Tempered"'. In Personality Cults in Stalinism, edited by Klaus Heller and Jan Plamper, 415-42. Göttingen: V\&R Unipress, 2004.

Davies, Sarah. "Us against Them": Social Identity in Soviet Russia, 19341941'. In Stalinism: New Directions, edited by Sheila Fitzpatrick, 47-69. London: Routledge, 2000.

Getty, J Arch, Gàbor T Rittersporn and Viktor N Zemskov. 'Victims of the Soviet Penal System in the Pre-War Years: A First Approach on the Basis of Archival Evidence'. American Historical Review 98 (Oct, 1993): 1017-1049.

Halfin, Igal. 'The Demonization of the Opposition: Stalinist Memory and the 'Communist Archive' at Leningrad Communist University'. Kritika 2 (Winter, 2001): 45-80.

Halfin, Igal. 'Looking into the Oppositionists' Souls: Inquisition Communist Style'. Russian Review 60 (July, 2001): 316-39.

Harris, James R. 'The Growth of the Gulag: Forced Labour in the Urals Region, 1929-1931'. Russian Review 56 (Apr, 1997): 265-280.

Hellbeck, Jochen. 'Fashioning the Stalinist Soul: The Diary of Stepan Pudlubnyi, 1931-1939'. In Stalinism: New Directions, edited by Sheila Fitzpatrick, 77-116. London: Routledge, 2000.

Hellbeck, Jochen. 'Working, Struggling, Becoming: Stalin Era Autobiographical Texts'. Russian Review 60 (Jul., 2003): 340-59. 
Lenoe, Matthew. 'Sarah Davies, Popular Opinion in Stalin's Russia: Terror, Propaganda, and Dissent, 1934-1941'. The Journal of Modern History, 71 (September, 1999): 789-91.

Nordlander, David J. 'Origins of a Gulag Capital: Magadan and Stalinist

Control in the Early 1930s'. Slavic Review 57 (Winter, 1998): 791-812.

Plamper, Jan. 'Foucault's Gulag'. Kritika 3 (Spring, 2002): 255-280.

Razgon, Lev. 'Jailers'. In Gulag Voices, An Anthology, edited by Anne Applebaum, 145-50. London: Yale University Press, 2011.

Rimmel, Lesley A. 'Another Kind of Fear: The Kirov Murder and the End of Bread Rationing in Leningrad'. Slavic Review 56 (Autumn, 1997): 48189.

Rittersporn, Gábor Tamás. 'Pressa Gulaga (1918-1955), and; The Gulag Press, 1920-1937'. Kritika 5 (Summer, 2004): 599-610.

Siegelbaum, Lewis H. 'Production Collectives and Communes and the "Imperatives" of Soviet Industrialization, 1929-1931'. Slavic Review 45 (Spring, 1986): 65-84.

Volkov, Vadim. 'The Concept of Kul'turnost'. Notes on the Stalinist Civilizing Process'. In Stalinism, New Directions, edited by Sheila Fitzpatrick, 21030. London: Routledge, 2000.

\section{Secondary Sources: Unpublished Materials}

Barenberg, Alan. 'From Prison Camp to Mining Town: The Gulag and its Legacy in Vorkuta, 1938-1965'. Ph.D. Thesis, University of Chicago, 2007. 